\title{
Titanium Oxide Nanotubes: Synthesis of Anatase Phase, Characterization and Photocatalytic Application
}

\author{
Filho, J. T.; Rocco, A. M.*
}

Rev. Virtual Quim., 2013, 5 (4), 630-645. Data de publicação na Web: 18 de agosto de 2013

http://www.uff.br/rvq

\section{Nanotubos de Óxido de Titânio: Síntese da Fase Anatásio, Caracterização e Aplicação Fotocatalítica}

Resumo: No presente trabalho, os nanotubos de óxido de titânio foram preparados pelo método de anodização. Neste processo uma chapa do metal titânio foi utilizada como eletrodo de trabalho, sendo o substrato para o crescimento de nanotubos. Uma lâmina de platina foi utilizada como contra-eletrodo. Os nanotubos de óxido de titânio foram sintetizados sob diferentes potenciais (20, 25 e $30 \mathrm{~V}$ ), e como eletrólito foram usadas soluções aquosas de $\mathrm{NaF}$ com concentrações de 0,018 e 0,036 M. As amostras obtidas foram caracterizadas por microscopia eletrônica de varredura, espectroscopia Raman e difração de raios- $\mathrm{X}$, antes e após o processo de recozimento. Todas as amostras após o tratamento térmico exibiram na sua estrutura cristalina exclusivamente a fase de anatásio, com formação bem definida de nanotubos. Foi possível também demonstrar a dinâmica de crescimento dos nanotubos de óxido de titânio, durante o processo de anodização das amostras. A atividade fotocatalítica dos nanotubos de óxido de titânio foi avaliada utilizando-se uma solução aquosa de clorofórmio, tendo sido observada fotodegradação de $51,58 \%$.

Palavras-chave: Nanotubos; óxido de titânio; fotocatálise.

\begin{abstract}
s
In the present work, titanium oxide nanotubes were prepared by potentiostatic anodization. A titanium sheet was used as working electrode, serving as substrate for the nanotubes growth. Titanium oxide nanotubes were synthesized under different anodization potentials $(20,25$ and $30 \mathrm{~V}$ ) in 0.18 and $0.36 \mathrm{M} \mathrm{NaF}$ aqueous solutions. The samples were characterized by scanning electron microscopy, Raman spectroscopy and X-ray diffraction, before and after a thermal treatment. All samples exhibited only the anatase phase after thermal treatment, for which the formation of well-defined nanotubes was observed. The dynamic growth of titanium oxide nanotubes during the anodization process was confirmed experimentally. The photocatalytic activity of the titanium oxide nanotubes was evaluated for chloroform oxidation, exhibiting photodegradation of $51.58 \%$.
\end{abstract}

Keywords: Nanotubes; titanium oxide; anatase; photocatalysis.

\footnotetext{
* Universidade Federal do Rio de Janeiro, Grupo de Materiais Condutores e Energia, Escola de Química, CEP 21941-909, Rio de Janeiro-RJ, Brasil.

Mamrocco@eq.ufri.br

DOI: $10.5935 / 1984-6835.20130045$
} 


\title{
Titanium Oxide Nanotubes: Synthesis of Anatase Phase, Characterization and Photocatalytic Application
}

\author{
Jorge Trota Filho, ${ }^{a, b}$ Ana Maria Rocco ${ }^{a, *}$
}

a Universidade Federal do Rio de Janeiro, Grupo de Materiais Condutores e Energia, Escola de Química, CEP 21941-909, Rio de Janeiro-RJ, Brasil.

${ }^{\mathrm{b}}$ Instituto de Nacional de Metrologia Qualidade e Tecnologia - Inmetro, CEP 25250-020, Duque de Caxias-RJ, Brasil.

*amrocco@eq.ufrj.br

Recebido em 22 de novembro de 2013. Aceito para publicação em 15 de agosto de 2013

\section{Introduction}

\section{Materials and Method}

2.1. Materials and samples preparation

2.2. Morphological analysis

2.3. Crystallographic analysis

2.4. Spectroscopic analysis

2.5. Photocatalytic tests

\section{Results and Discussion}

3.1. Current density vs time

3.2. Morphology

3.3. Crystallographic and spectroscopic characterization

3.4. Photocatalytic efficiency

\section{Conclusions}

\section{Introduction}

The successful synthesis of carbon nanotubes by lijima in 1991 has stimulated an intense research on new nanoscale materials and its importance is clearly seen in the development of nanotechnology and its implications. ${ }^{1} \quad$ Carbon nanotubes exhibit enhanced properties compared to other carbon forms as well as directionality dependence, confinement and quantum effects related to the nanometer scale. About a decade later, the successful chemical synthesis of other nanotubes, particularly transition metal oxide nanotubes, was established. ${ }^{2}$ In 1998, Kasuga et al firstly prepared $\mathrm{TiO}_{2}$ nanotubes $\left(\mathrm{TiO}_{2}-\mathrm{NT}\right)$ from $\mathrm{NaOH}$ aqueous solutions and $\mathrm{TiO}_{2}$ nanoparticles as precursors. ${ }^{3,4}$

$\mathrm{TiO}_{2}$-NT with controlled morphologies and in large quantities can be obtained by several well-established synthetic methods, such as 
hydrothermal, ${ }^{5}$ sol-gel ${ }^{6}$ and electrochemical synthesis. ${ }^{7} \quad$ Anodization is particularly interesting due to the production of $\mathrm{TiO}_{2}$-NT directly attached to the Ti substrate foil. ${ }^{8}$

Titanium oxide exists in three allotropic forms, anatase, rutile and brookite, the first two being the most commonly found. The latter is not easily obtained due to its inherent instability. ${ }^{4-6}$ At approximately 915 ${ }^{\circ} \mathrm{C}$, the anatase structure changes to rutile, which is the most common form of titanium oxide, while anatase phase is less thermodynamically stable and is found in smaller quantity when compared with rutile phase. The anatase phase exhibits similar properties to those of rutile, such as hardness and density. However, due to the different crystalline structures of anatase and rutile namely a small difference in the way of crystallization and a large difference in cleavage promotes the development of different properties between the phases anatase and rutile. ${ }^{9,10}$

The inactivity of the rutile phase for photodegradation of organic compounds is known, however, this characteristic is still not fully understood. However, the low $\mathrm{O}_{2}$ adsorption on the solid surface has been suggested as a possible factor. ${ }^{4,6,11,12}$

According to $\mathrm{Li}$ et al., heat treatment at $400{ }^{\circ} \mathrm{C}$ and $500{ }^{\circ} \mathrm{C}$ does not induce rutile phase formation. ${ }^{13}$ Heating rates higher than $25^{\circ} \mathrm{C} / \mathrm{min}$ probably induces the formation of rutile phase due to the low thermodynamic stability of anatase compared to rutile. ${ }^{4-6}$

According to other authors, the assynthesized $\mathrm{TiO}_{2}$ nanostructures are usually amorphous and crystallize into different phases by adjusting the thermal treatment parameters. ${ }^{14,15}$ The untreated amorphous $\mathrm{TiO}_{2}$ gradually crystallizes into anatase phase after heat treatment under moderate temperatures (200 to $400{ }^{\circ} \mathrm{C}$ ), although between 500 and $600{ }^{\circ} \mathrm{C}$, the solid shows a highly crystalline structure and, due to the temperature increase, an irreversibly phase transition from anatase to rutile was observed by increasing the temperature from $400{ }^{\circ} \mathrm{C}$ to $1200{ }^{\circ} \mathrm{C}$. Kinetic studies of the phase transformation from anatase to rutile in $\mathrm{TiO}_{2}$ particles showed that process is strongly dependent on the crystal size, interface and purity. Therefore, if $\mathrm{TiO}_{2}$ nanotubes are to be used in low temperature applications, the consideration about phase transitions is irrelevant. ${ }^{14,15}$

The $\mathrm{Ti}$ anodization to form oxide layers have been investigated for decades, using different electrolytic conditions such as different acids, organic solvents and salt solutions. However, the first results that showed nanotube ordering were obtained by Zwilling et al. in $1999 .{ }^{16}$ This first $\mathrm{TiO}_{2}$-NT synthetic approach resulted in a disordered layer of no more than 500 nm-thick. Nanotubes with enhanced structure were obtained by Macak et al., which employed finely $\mathrm{pH}$ control and nonaqueous electrolytes. ${ }^{17}$ Currently, $\mathrm{TiO}_{2}$-NT arrays are obtained in hexagonally ordered arrays, as a nearly ideal crystallographic structure, with tube diameters ranging from 10 to or greater than $200 \mathrm{~nm}^{2}$

The control of electrochemical parameters such as the form of the applied potential, different morphologies can be obtained. These are nanoscale structures such as stacked layers, nanobamboos, branched tubes, multiwall tubes as well as amphiphilic $\mathrm{TiO}_{2}-\mathrm{NT} .^{5}$

Nanotubes are interesting structures due to their high surface-to-volume ratio and size-dependent properties. Early researches have shown the superior properties of titanium oxide nanotubes compared to of titanium oxide structures for several applications. These nanotubes can be used in photocatalysis, ${ }^{18}$ sensors, ${ }^{19}$ photoelectrocatalysis, ${ }^{20}$ photovoltaic generation and dye-sensitized solar cells. ${ }^{21-23}$ For these applications, the control of nanotube dimensions is essential for the achievement of enhanced properties. Parameters such as outer diameter and tube length have strong impact on their performance. In order to achieve and control these properties, different fluoridecontaining electrolytes have been used to increase the nanotubes length ( $L$ ): (i) aqueous 
HF electrolyte $(\mathrm{L}<500 \mathrm{~nm}),{ }^{24}$ (ii) aqueous $\mathrm{pH}$ sputtered fluoride electrolytes $(\mathrm{L}<6 \mu \mathrm{m})^{25}$ and (iii) fluoride-containing polar organic electrolytes $(L>6 \mu \mathrm{m}){ }^{26}$

In the presence of an appropriate catalyst, the photocatalytic process readily promotes the photolytic reaction. These photoinduced reactions are activated by absorption of photons with sufficient energy to promote the electron flow from the valence band to the band gap which migrate then to the conduction band of the catalyst. As a consequence, an electron-hole pair is created, inferring photocatalytic activity to the material.

Photocatalytic processes are based on the direct or indirect use of solar radiation which enables water splitting, providing a clean and sustainable source of both hydrogen and oxygen. The applicability of titanium oxide nanotubes is pointed as promising due to their photocatalytic properties, characteristic of an ordered nanostructured material. ${ }^{27}$ Another important feature is the low cost of titanium oxide, which is a desirable characteristic for its economical viability. Compared to other methods and materials, the use of titanium oxide in effluent remediation is advantageous over traditional chemical methods, due to absence of reagents consumption.

The aim of the present work is to obtain titanium oxide nanotubes $\left(\mathrm{TiO}_{2}-\mathrm{NT}\right)$ by electrochemical synthesis and the evaluation of the photocatalytic properties in a chloroform aqueous solution.

\section{Materials and Method}

\subsection{Materials and samples preparation}

A DC power supply unit (Extech Instruments - model 382260) and a Teflon ${ }^{\circledR}$ single compartment electrochemical cell with two electrodes were used in the synthesis setup. A $1 \mathrm{~cm}$ wide, $2.5 \mathrm{~cm}$ long and $0.5 \mathrm{~mm}$ thick platinum plate was used as the counter electrode and the $\mathrm{TiO}_{2}$ nanotubes were obtained by anodization from a pure titanium foil $\left(99.6 \%, 0.5 \mathrm{~mm}\right.$ thickness) of $5 \times 3 \mathrm{~cm}^{2}$.

The substrate surface preparation was performed by sanding one of the faces of the specimens with a series of sandpapers (silicon carbide, SiC, 220- through 1200-grit), followed by polishing with alumina and cleaning in ultrasound bath during 30 minutes for each step, first in isopropyl alcohol p.a. and then in acetone p.a. (both supplied by Aldrich Chem. Co). Table 1 shows the synthesis conditions for each sample, including $\mathrm{NaF}$ concentration, potential and anodization time.

The titanium plate was connected to the positive pole of the DC power supply, while the platinum counter electrode was connected to the negative one. The distance between the two electrodes (the titanium sheet and the platinum counter electrode) was kept at $1 \mathrm{~cm}$. After the electrochemical synthesis, the samples were subjected to a heat treatment in a tubular furnace (EDG model 10P-S) under argon atmosphere. The samples were heated until $500{ }^{\circ} \mathrm{C}\left(25^{\circ} \mathrm{C} / \mathrm{min}\right)$ and maintained at this temperature for 3 hours.

Photocatalytic tests were performed after the heat treatment. Titanium nanotubes supported onto titanium metal sheets were put into contact with a $0.012 \mathrm{M} \mathrm{CHCl}_{3}$ aqueous solution during $1 \mathrm{~h}$.

The photocatalytic degradation was evaluated by chemical oxygen demand (COD), being performed in a $\mathrm{HACH}$ digester and analyzed by a HACH DR 2800 spectrophotometer. The test was performed before and after the reaction employing only UV radiation and after the reaction using both UV radiation and the titanium oxide nanotube samples. 
Table 1. Syntheses conditions for each sample, including electrolyte concentration, anodization potential and time

\begin{tabular}{|c|c|c|c|}
\hline Sample & {$[\mathrm{NaF}] / \mathrm{M}$} & $\begin{array}{c}E / V \\
D C\end{array}$ & Time/h \\
\hline$A_{1}$ & 0.18 & 20 & 2 \\
\hline$A_{2}$ & 0.18 & 25 & 2 \\
\hline$A_{3}$ & 0.18 & 30 & 2 \\
\hline$A_{4}$ & 0.18 & 25 & 1 \\
\hline$A_{5}$ & 0.18 & 20 & 4 \\
\hline$A_{6}$ & 0.18 & 25 & 4 \\
\hline$A_{7}$ & 0.18 & 30 & 1 \\
\hline$A_{8}$ & 0.18 & 30 & 4 \\
\hline$A_{9}$ & 0.18 & 20 & 1 \\
\hline$A_{10}$ & 0.36 & 25 & 4 \\
\hline$A_{11}$ & 0.36 & 30 & 2 \\
\hline$A_{12}$ & 0.36 & 20 & 2 \\
\hline$A_{13}$ & 0.36 & 20 & 1 \\
\hline$A_{14}$ & 0.36 & 20 & 4 \\
\hline$A_{15}$ & 0.36 & 30 & 4 \\
\hline$A_{16}$ & 0.36 & 25 & 2 \\
\hline$A_{17}$ & 0.36 & 30 & 1 \\
\hline$A_{18}$ & 0.36 & 25 & 1 \\
\hline
\end{tabular}

\subsection{Morphological analysis}

The morphology of the samples was analyzed by scanning electron microscopy (SEM) in a JEOL - JSM-6490LV electron microscope. The images were obtained under high vacuum and at a $30 \mathrm{kV}$ accelerating voltage.

\subsection{Crystallographic analysis}

X-ray diffraction (XRD) patterns of the samples were obtained in a Rigaku diffractometer (Rigaku, Miniflex II). All the diffratograms were obtained in an angular range from $10^{\circ}$ to $90^{\circ}$, employing $\mathrm{Cu} \mathrm{K}$ ? radiation.

\subsection{Spectroscopic analysis}

The Raman spectra were obtained in a
Horiba HR800 spectrometer. This technique provided the vibrational modes related to the titanium-oxygen bonds in each sample. The experimental setup employed a $100 x$ magnification, scanning range between 100 and $1000 \mathrm{~cm}^{-1}$, exposure time of $150 \mathrm{~s}$, RTD exposure time $1 \mathrm{~s}$, accumulation number 2 , filter none, red laser $\lambda=632.81 \mathrm{~nm}$ and resolution 1800.

\subsection{Photocatalytic tests}

The tests were performed in a photocatalytic reactor which contained a UV energy source. The photocatalytic process was performed through a heat exchanger in order to prevent large temperature variations during the photocatalytic process. Figure 1 shows a schematic drawing of the experimental apparatus used during the photocatalytic reaction. 


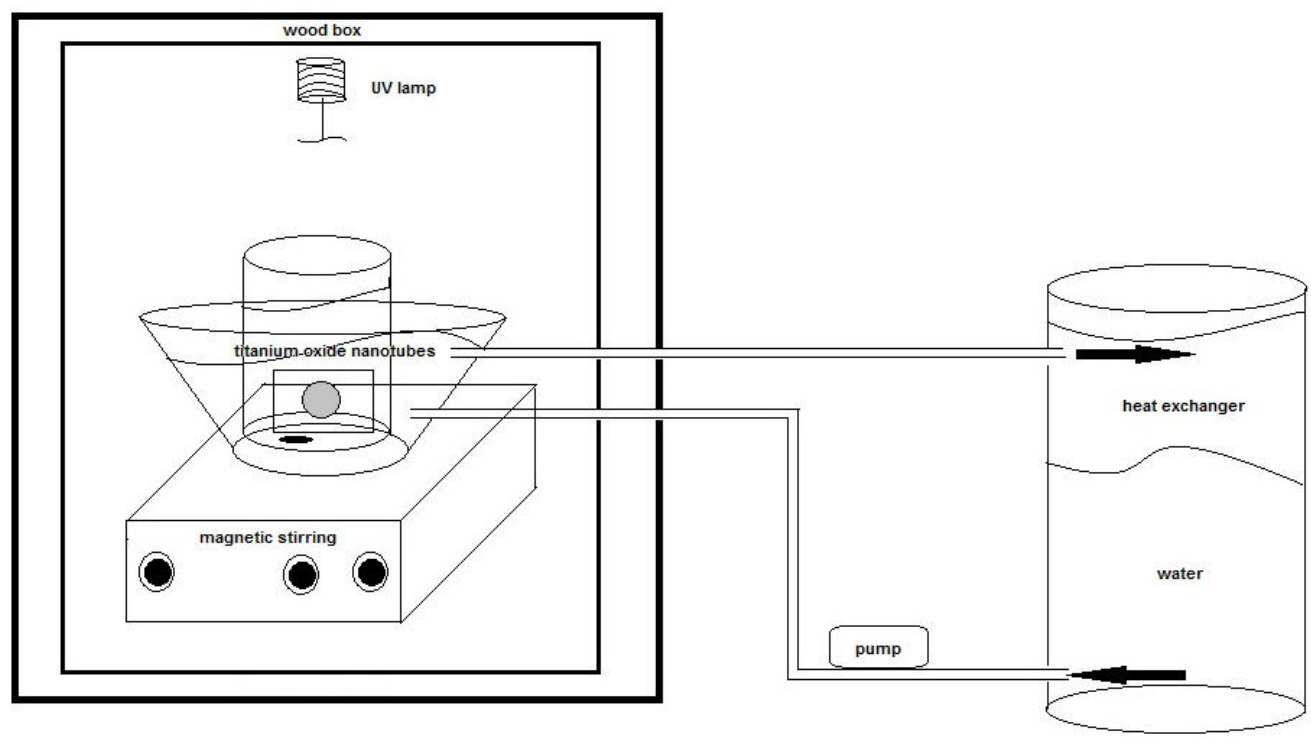

Figure 1. Schematic photocatalytic system ${ }^{27}$

\section{Results and Discussion}

\subsection{Current density vs time}

All samples were synthetized according to the conditions listed in Table 1 and the current density was monitored during anodization. Figure 2 shows the current density as a function of time during the synthesis of $A_{6}, A_{8}$, and $A_{10}$ samples. As clearly seen, the current density rapidly decreases after the start of the anodization process. This can be associated to the growing of the titanium oxide layer, stabilized under variation of the current density due to the titanium oxide redissolution and growing (thickening) process. The current density stabilization (with time) indicates that the anodization process has reached the chemical equilibrium. These results are in accordance to Beranek and Zhao, who observed and associated this phenomenon to the solubility of the titanium oxide in fluoride solutions. ${ }^{28,29}$ During anodization, the pores on the titanium oxide film tend to grow randomly, as the current density varies with time and, during the pore growing process, the current density decreases and reaches a stable value, for which highly ordered and aligned arrays of titanium oxide nanotubes have been formed. ${ }^{28,29}$

In the samples $A_{1}, A_{2}, A_{3}, A_{4}, A_{5}, A_{7}, A_{9}, A_{11}$, $A_{12}, A_{13}, A_{14}, A_{15}, A_{16}, A_{17}$ and $A_{18}$ were not possible to establish a state of equilibrium between the change in current density and time. Thus, the surface morphology were not observed to produce arrays of nanotubes of titanium oxide. 


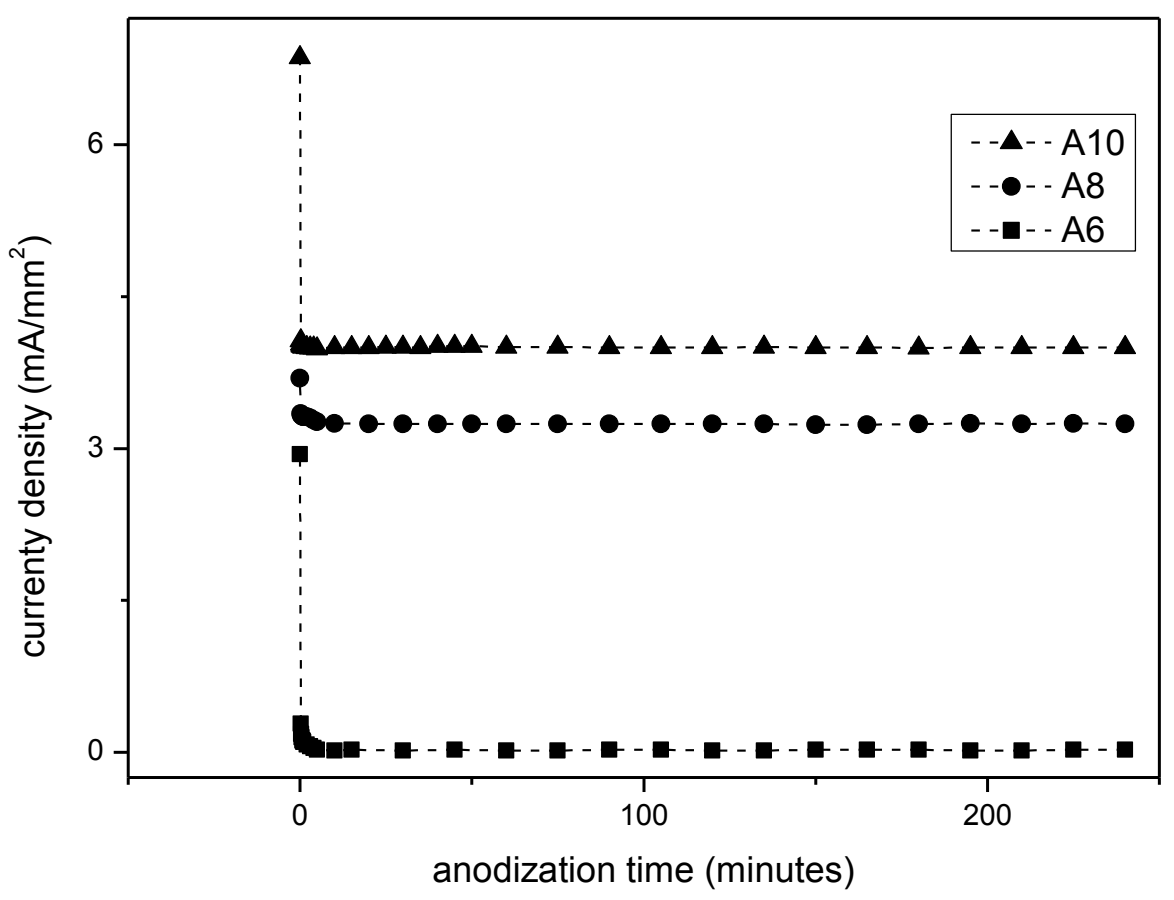

Figure 2. Current density as a function of time for samples $A_{6}, A_{8}$ and $A_{10}$ during the anodization process

\subsection{Morphology}

All $\mathrm{TiO}_{2}$-NT samples were characterized by SEM, exhibiting different morphologies depending on the synthesis conditions. Representative SEM images of selected samples are shown in Figures 3 and 4.

\subsubsection{Applied potential effect}

SEM images represented in Figure 3 evidence the best conditions for nanotube production among those employed in the present work (potential between 25 (a) and $30 \mathrm{~V}$ (c) during 4 hours). These images indicate that morphological homogeneity is affected by the synthesis conditions, strongly depending on the anodic oxidation potential. Samples obtained under $30 \mathrm{~V}$ exhibited more homogeneous morphologies and exhibited larger nanotube diameters than the samples obtained under $25 \mathrm{~V}$. A similar behavior was observed by Zhao et al., which synthesized $\mathrm{TiO}_{2}$-NT during 30 minutes using HF solutions as electrolyte. ${ }^{29}$ Similarly to the behavior observed in the present work, the authors have concluded that the potential increase from 20 to $30 \mathrm{~V}$ led to an increase in the pore diameter of the $\mathrm{TiO}_{2}-\mathrm{NT}$.

According to analyses of SEM images, the experimental conditions applied to the samples $A_{2}-A_{5}, A_{7}, A_{9}$ and $A_{11}-A_{18}$ (described in Table 1) were not appropriate to synthesize $\mathrm{TiO}_{2}$ nanostructures. In order to observe the nanotubes formation, a balance between the dissolution process and the growth of the oxide layer induced by anodic current is necessary. To meet these conditions, parameters such as type and concentration of electrolyte, anodization potential and time have to be studied and controlled. ${ }^{29}$ 


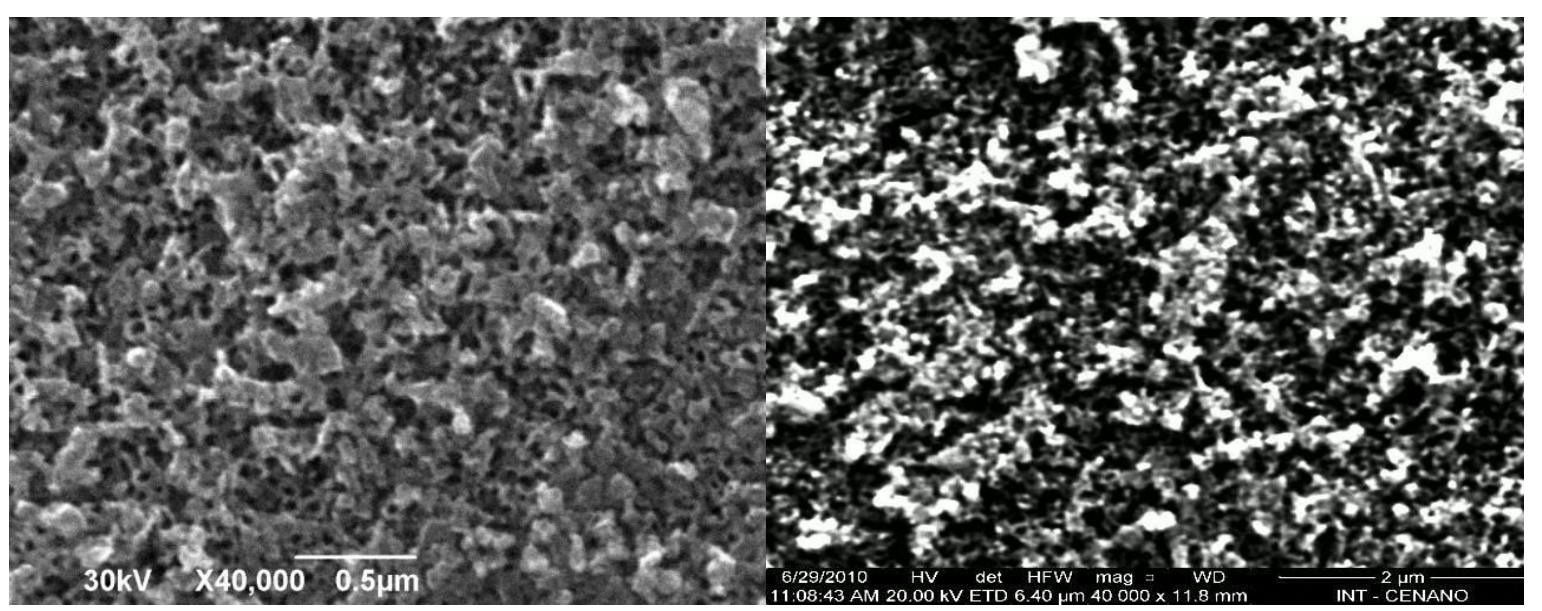

(a)

(b)

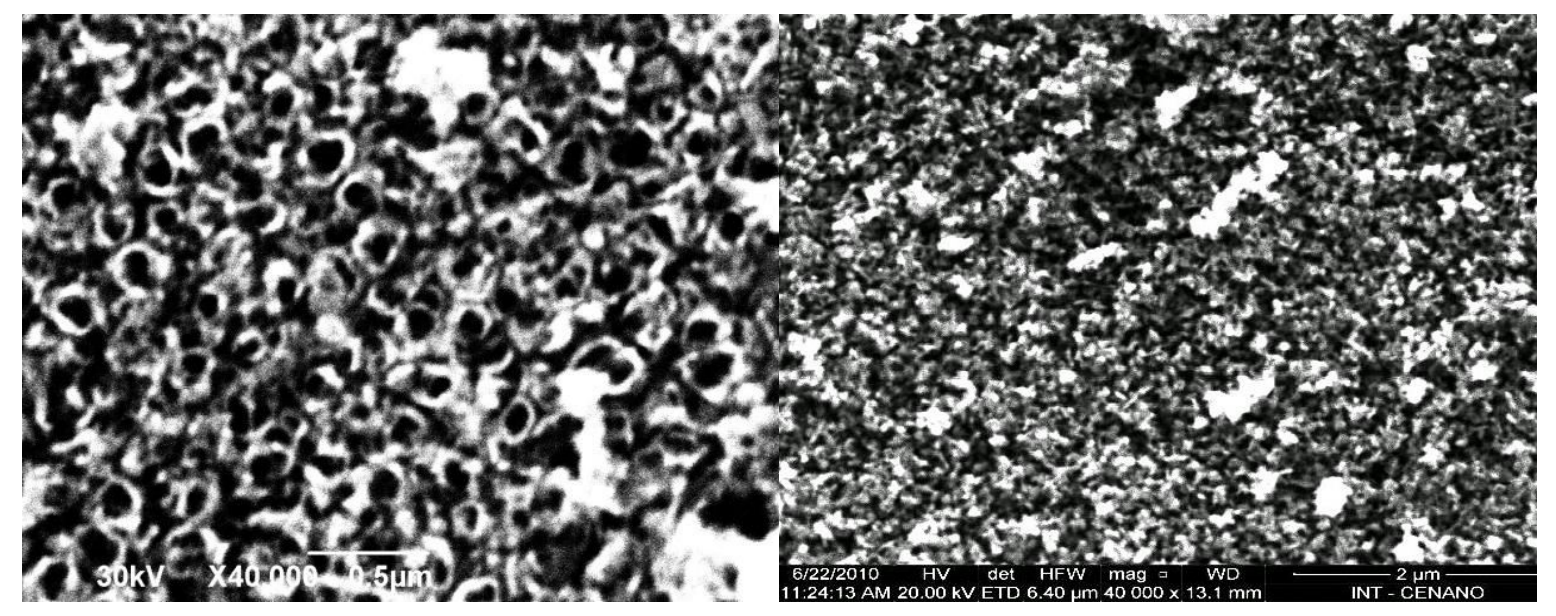

(c)

(d)

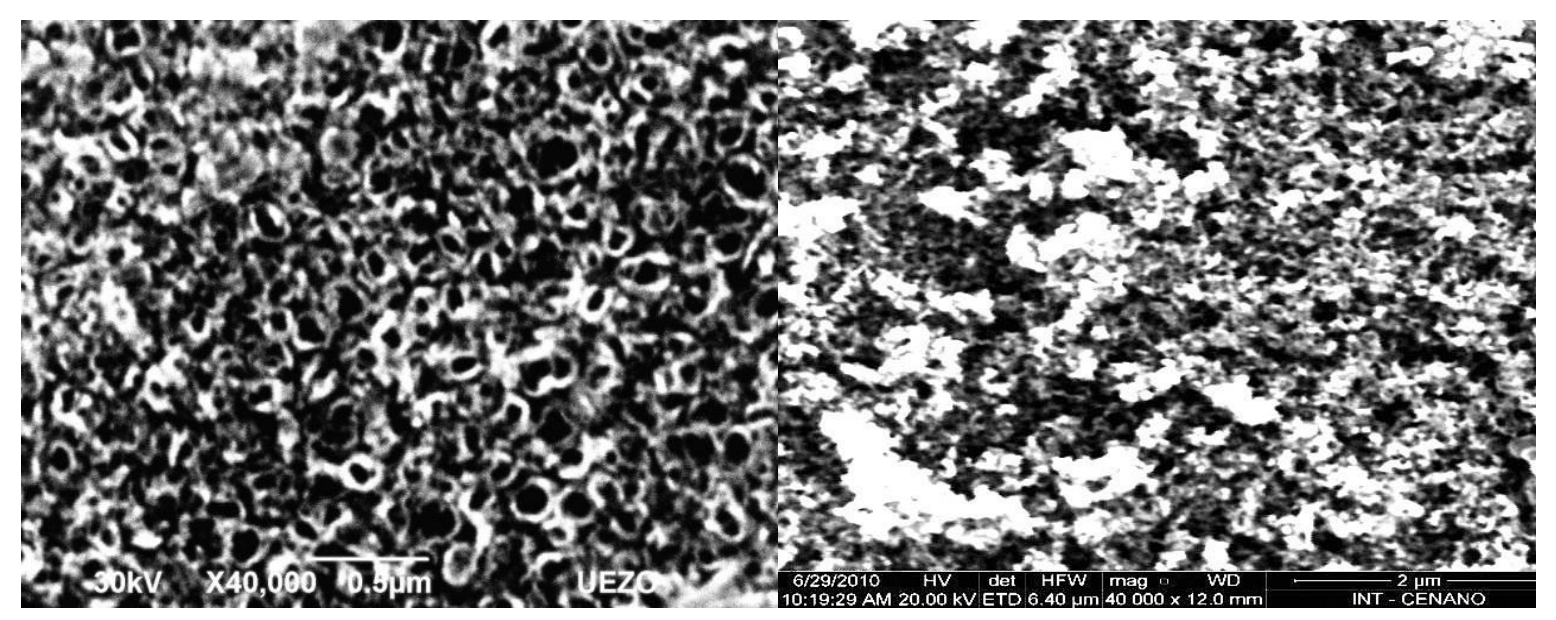

(e)

(f)

Figure 3. SEM images of samples $A_{6}, A_{8}, A_{10}$ before $(a, c, e)$ and after $(d, e, f)$ the heat treatment

As pointed by $\mathrm{Xu}$ et al., the electrochemical growth of porous titanium oxide in HF solutions is different from that observed for aluminum oxide. $^{30}$ The development of $\mathrm{TiO}_{2}-\mathrm{NT}$ arrays on the surface of a titanium substrate can be described as 
follows: (i) a thin oxide layer is formed on the titanium surface, which corresponds to a rapid decrease in the current density in this first stage of oxidation; (ii) the resulting mechanical stress in this oxide layer is mainly due to both volume and density changes that accompany the titanium oxidation; (iii) the formation of a crystalline oxide occurs during the stress event and, as a consequence, the crystallinity leads to a density increase for both anatase or rutile structures, resulting in a stress relaxation in the oxide layer. ${ }^{30}$

This crystalline transition under stress is strongly related to the dielectric boundary breakdown. The selective dissolution occurs due to differences between the internal tensions present in the crystalline structures. Initially, the pores are irregularly formed due to a non-uniform corrosion process and the rates of dissolution and oxidation are different in pores with different diameters. Under favorable experimental conditions, formation of uniform pores will occur during the anodizing process, leading to regular porous structures. ${ }^{30}$

This phenomenon of nanotube growth takes place probably due to an increase in the dissolution rate of titanium oxide on the surface of the titanium foil at a higher potential values. This is an indication that chemical dissolution is assisted by the electric field during synthesis. Under the applied potential, the titanium-oxygen bonds undergo polarization and weakening, with an increase in the titanium oxide dissolution as a consequence. $^{31}$

\subsubsection{Electrolyte concentration effect}

The behavior of $A_{6}, A_{8}$ and $A_{10}$ samples indicates the effect of electrolyte concentration, similarly to the results obtained by Xiao et al.. ${ }^{32}$ However, the authors used different electrolytes with different concentrations, which prevented to decide the key parameter for the morphology control. In the present work, the results showed that both the high electrolyte concentration and, consequently, high ionic conductivity, induced high rates of titanium oxide layer dissolution. This feature led to the formation of a larger fraction of $\mathrm{TiO}_{2}-\mathrm{NT}$ in sample $A_{10}$ compared to sample $A_{6}$.

\subsubsection{Heat treatment effect}

According to the SEM images shown in Figure 3, changes were observed in the surface morphology of the samples after heat treatment in the presence of argon atmosphere. These changes can be attributed to the growth-induced oxide layer, which modified the inner diameter of the $\mathrm{TiO}_{2}-\mathrm{NT}$ (pore size) and promoted sintering of some extent of $\mathrm{TiO}_{2}$-NT (Figure 3 (b)). This effect was observed by other authors; for instance, Mor et al. observed inner diameter decrease and an increase of the $\mathrm{TiO}_{2}$-NT wall thickness as a consequence of heat treatment. $^{21}$

3.2.4. Time and electrolyte concentration effects on the $\mathrm{TiO}_{2}-\mathrm{NT}$ growing

Figure 4 shows SEM images obtained at different anodization times for the same electrolyte concentration and applied potential, confirming the formation of $\mathrm{TiO}_{2}$ NT. The initial step of the $\mathrm{TiO}_{2}-\mathrm{NT}$ formation is detected in Figure 4a (parameters $[\mathrm{NaF}]=0.18 \mathrm{M}, \mathrm{V}=25 \mathrm{~V}$ and $1 \mathrm{~h}$ ), where there an oxidized porous surface observed will nucleate the nanotubes formation. A heterogeneous $\mathrm{TiO}_{2}-\mathrm{NT}$ formation at the surface was observed after $2 \mathrm{~h}$ (Figure $4 \mathrm{~b}$ ) and, after $4 \mathrm{~h}$, some ordered nanotubular structures were formed, dispersed at the substrate surface. Under these conditions, the anodization time is a key parameter for the control of these nanotubular structures, being an evidence of a kinetic controlled process. These results are similar to those found in the work of Yu et al., who observed changes on the samples morphology for different experimental conditions and substrates. ${ }^{7}$ 


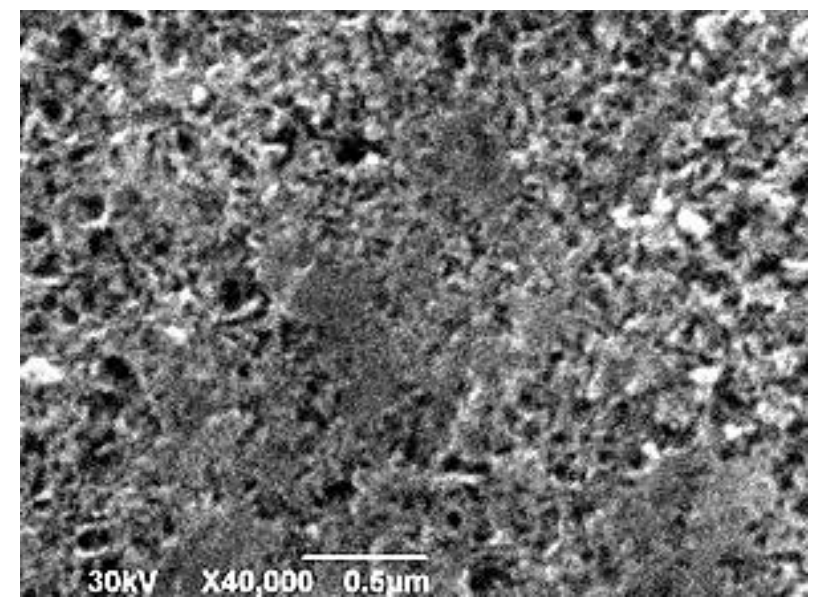

(a)

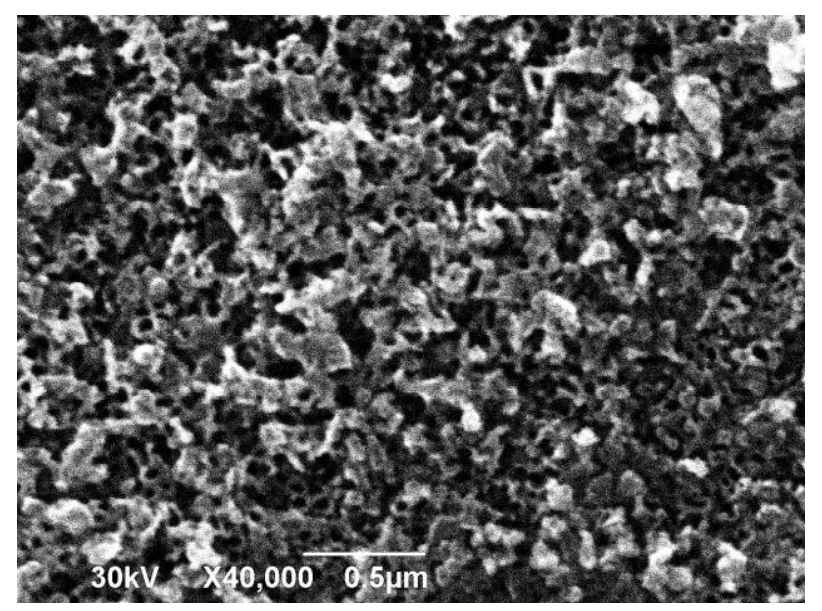

(c)

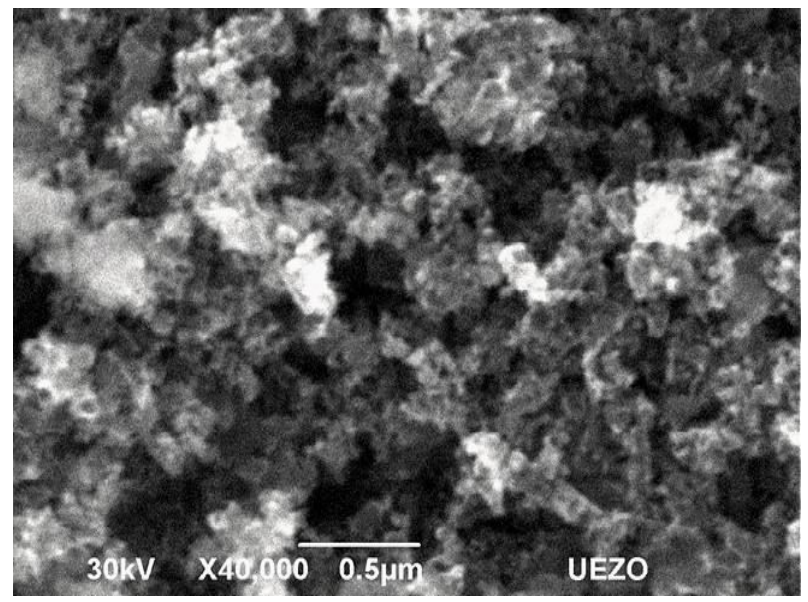

(e)

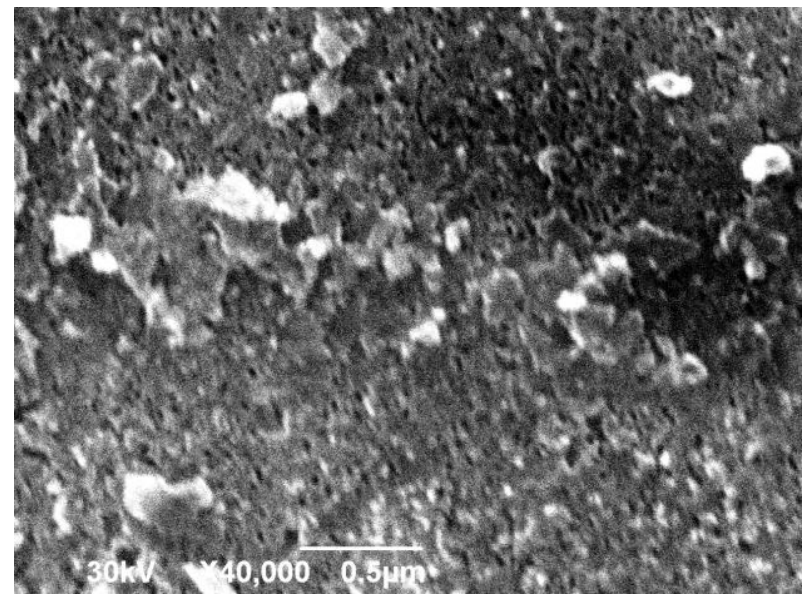

(b)

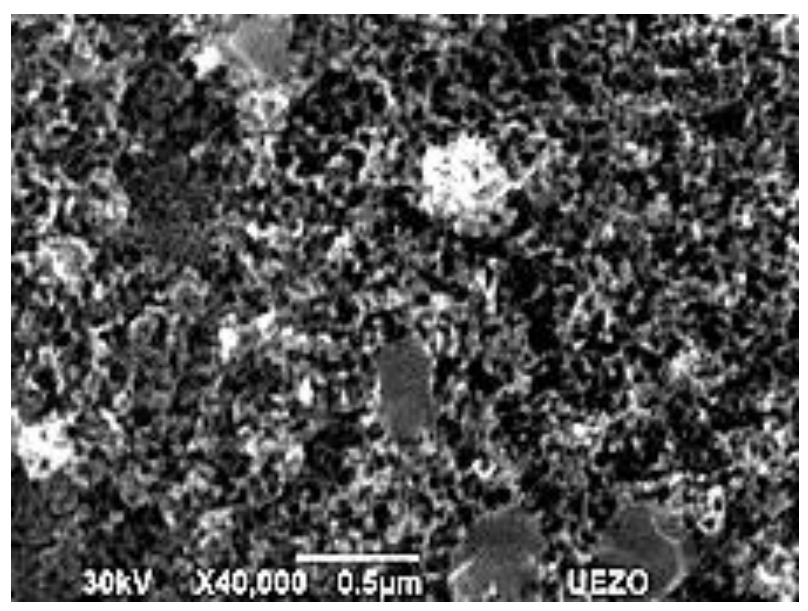

(d)

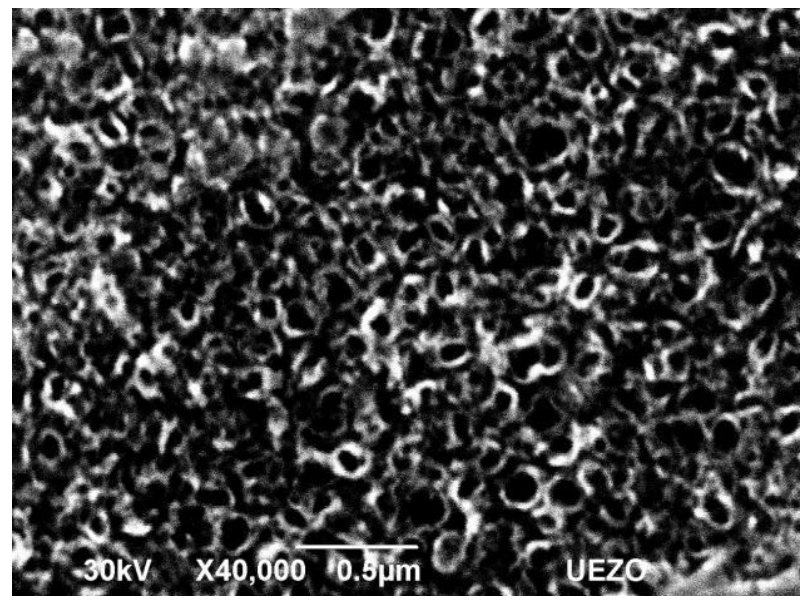

(f)

Figure 4. SEM images of sample obtained under $25 \mathrm{~V}$ in: (a) $[\mathrm{NaF}]=0.18 \mathrm{M}, \mathrm{t}=1 \mathrm{~h}$, (b) $[\mathrm{NaF}]=$ $0.18 \mathrm{M}, \mathrm{t}=2 \mathrm{~h},(\mathrm{c})[\mathrm{NaF}]=0.18 \mathrm{M}, \mathrm{t}=4 \mathrm{~h},(\mathrm{~d})[\mathrm{NaF}]=0.36 \mathrm{M}, \mathrm{t}=1 \mathrm{~h},(\mathrm{e})[\mathrm{NaF}]=0.36 \mathrm{M}, \mathrm{t}=2 \mathrm{~h}$ and $(\mathrm{f})[\mathrm{NaF}]=0.36 \mathrm{M}, \mathrm{t}=4 \mathrm{~h}$

Figures $4 d, 4 e$ and $4 f$ evidence the effect of electrolyte concentration (increasing from 0.18 to $0.36 \mathrm{M}$ ), which drastically alters the
$\mathrm{TiO}_{2}$-NT formation. The increase in fluoride concentration markedly influences the first steps of titanium oxidation, giving rise to an 
irregular distribution of $\mathrm{TiO}_{2}-\mathrm{NT}$, as shown after $1 \mathrm{~h}$ (Figure $4 \mathrm{~d}$ ). The formation of a small $\mathrm{TiO}_{2}-\mathrm{NT}$ concentration at the surface can be attributed to the high fluoride availability in solution, which accelerates the first oxidation steps, as suggested by the comparison among other similar conditions with different electrolyte concentrations. After $2 \mathrm{~h}$ (Figure 4e), however, a new oxide layer apparently covers the already formed nanostructures or, possibly, it is formed from the redissolution of the first oxide layer. Independently on the mechanism, its consequence is the loss of the porous structure at this initial stage. The formation of well-defined $\mathrm{TiO}_{2}-\mathrm{NT}$ structures was observed after $4 \mathrm{~h}$, as shown in Figure $4 \mathrm{f}$. The comparison of the parameters used to obtain these materials indicates the strong influence of both electrolyte concentration and time, allowing the formation of titanium oxide nanotubes with controlled diameter and distribution over a titanium surface. ${ }^{7}$

The SEM images shown in Figure 4 are in agreement with the mechanism proposed by Xu et al. for the growing of $\mathrm{TiO}_{2}-$ NT, which is based on the electrochemical growth of a porous titanium oxide layer at the titanium surface in HF solutions. ${ }^{30}$ Although the syntheses conditions used in the present work were different from the cited work, the growing of $\mathrm{TiO}_{2}$-NT occurred similarly, regardless of the higher polarity and conductivity of $\mathrm{NaF}$, the growing steps in $\mathrm{HF}$ solutions were very similar. According to other authors, electrolytes dissolved in organic solvents may induce a different $\mathrm{TiO}_{2}-$ NT formation and growing kinetics when compared to aqueous solutions. ${ }^{33}$

\subsection{Crystallographic and spectroscopic characterization}

\subsubsection{X-Ray diffraction analysis}

Samples $A_{6}, A_{8}$ and $A_{10}$ were characterized by X-ray diffraction (XRD) and Raman spectroscopy. Figure 5 shows the XRD patterns for (thermally) untreated samples between 10 and $70^{\circ}$, evidencing the peaks related to the titanium substrate at $35^{\circ}(100)$, $40^{\circ}(002), 42^{\circ}(101), 52^{\circ}(102)$ and $62^{\circ}$ (110). XRD patterns obtained before heat treatment showed low crystallinity (amorphous) and formation of a thin $\mathrm{TiO}_{2}$-NT layer. In Figure 6, the XRD patterns of samples $A_{6}, A_{8}$ and $A_{10}$ after the heat treatment are depicted. $A$ crystallinity increase and the presence of diffraction peaks at $25^{\circ}(101)$ associated with the titanium oxide nanotubes and at $38^{\circ}$ $(004)$ and $47^{\circ}(200)$ due to the anatase phase were observed in all diffractograms. ${ }^{34-36}$ 


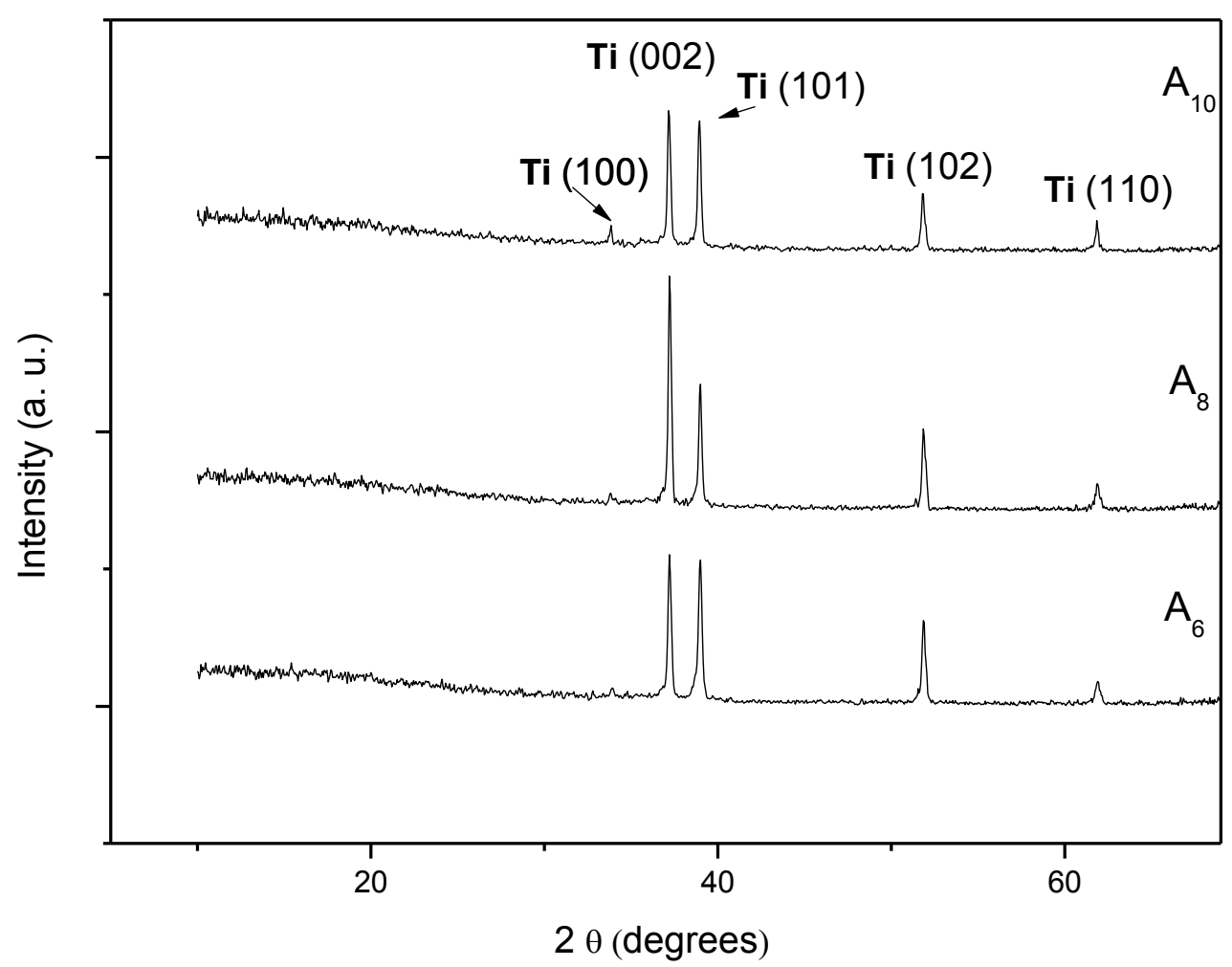

Figure 5. XRD patterns of samples $A_{6}, A_{8}$ and $A_{10}$ before the heat treatment

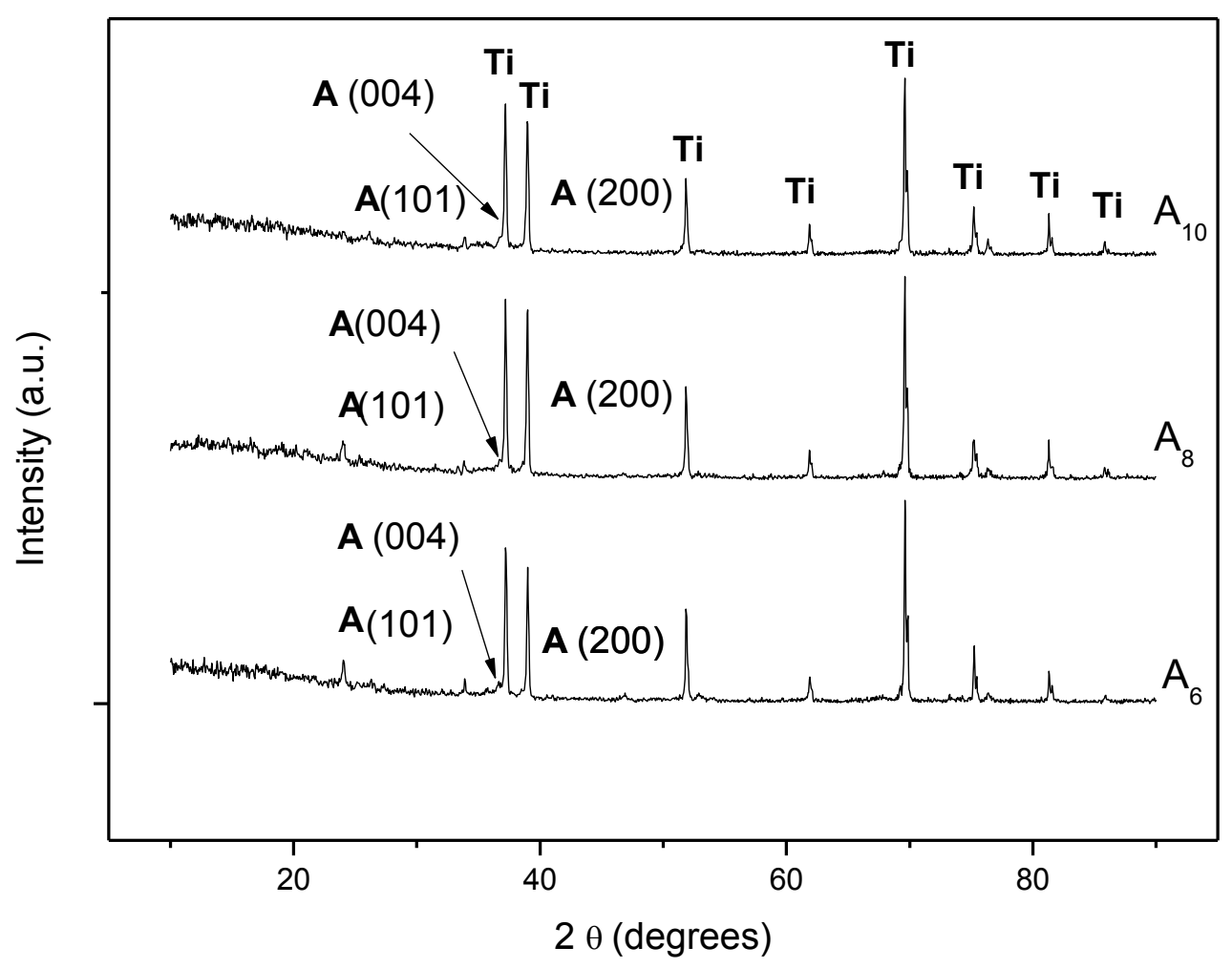

Figure 6. XRD patterns of samples $A_{6}, A_{8}$ and $A_{10}$ after the heat treatment 


\subsubsection{Raman spectroscopy analysis}

Figure 7 shows the Raman spectra of samples $A_{6}, A_{8}$ and $A_{10}$ before the heat treatment, in which the $\mathrm{TiO}_{2}$-NT layer detected is essentially an amorphous phase, as indicated by the Raman scattering bands. Even considering the low crystallinity of samples $A_{6}, A_{8}$ and $A_{10}$, a Raman scattering band at approximately $140 \mathrm{~cm}^{-1}$ corresponding to $\mathrm{TiO}_{2}-\mathrm{NT}$ and the bands at 400,500 and $630 \mathrm{~cm}^{-1}$ related to the anatase phase were detected.

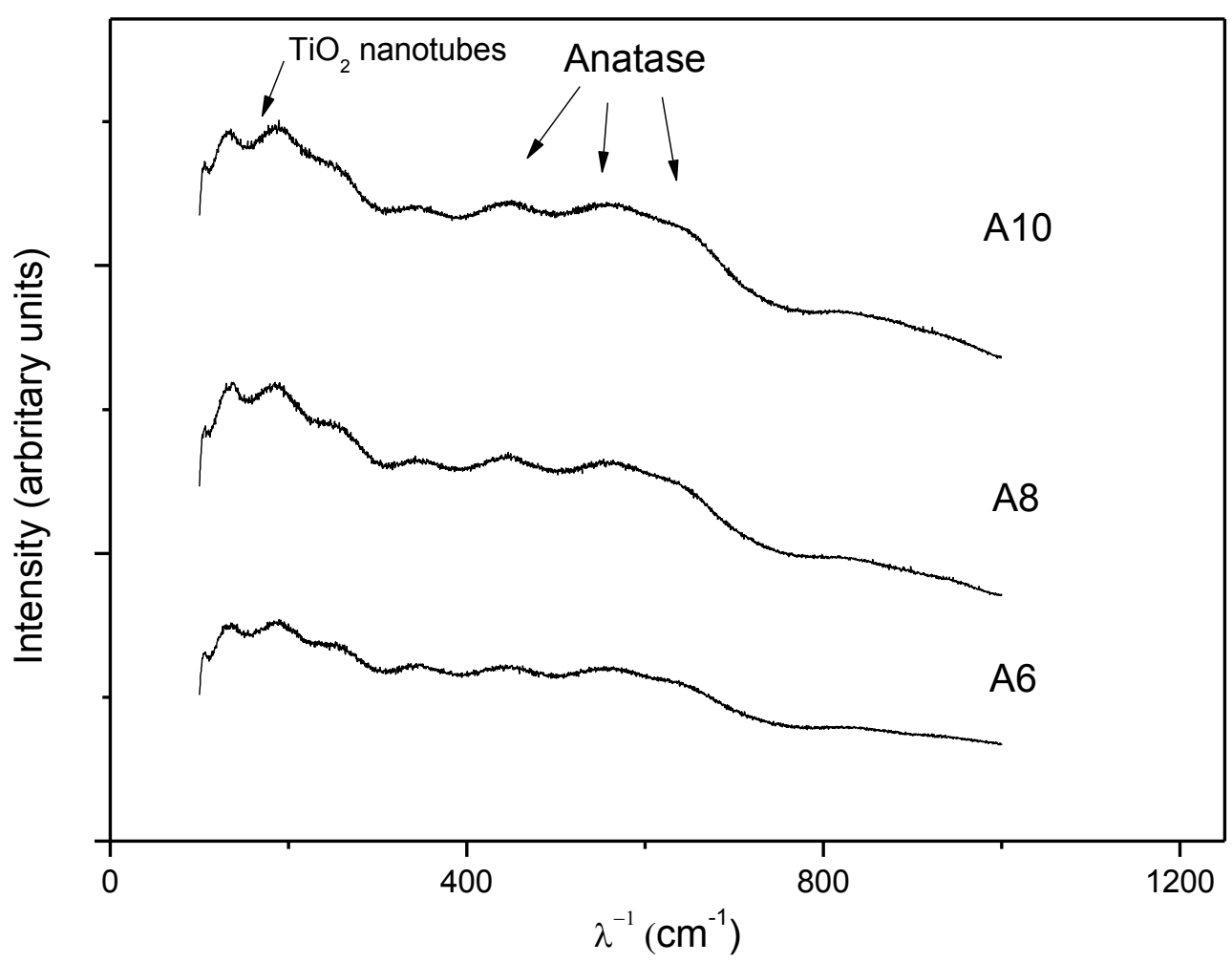

Figure 7. Raman Spectra of samples $A_{6}, A_{8}$ and $A_{10}$ before the heat treatment

Figure 8 shows the Raman spectra of $A_{6}$, $A_{8}$ and $A_{10}$ samples after heat treatment. $A$ crystallinity increase is observed, evidenced by sharpening and intensity of the Raman scattering bands at $140,400,500$ and $630 \mathrm{~cm}^{-}$ ${ }^{1}$. This behavior is generally observed after heat treatment, however, under these conditions the heat treatment induces the formation of rutile phase above $400{ }^{\circ} \mathrm{C}^{27,}{ }^{27}$ In the present work, the heat treatment was performed up to $500{ }^{\circ} \mathrm{C}$ and the only observed phase was anatase, which is the photocatalyticaly active phase, to be employed in photodegradation of organic compounds. ${ }^{37}$ Other authors observed the formation of anatase phase at $500{ }^{\circ} \mathrm{C}$ and rutile phase at $800{ }^{\circ} \mathrm{C}$ under argon atmosphere, using $300^{\circ} \mathrm{C} / \mathrm{min}$ as the heating rate while, in the present work, with a heating rate of $25{ }^{\circ} \mathrm{C} / \mathrm{min}$, anatase was the only obtained phase. ${ }^{38}$ In the same work, the heat treatment changed the $\mathrm{TiO}_{2}-\mathrm{NT}$ arrays into crystalline pores with random orientation. The importance of controlling the heating rate during thermal treatment resides in its relation with the ordering of crystalline structures in titanium oxide phases, as higher heating rates induce lower degrees of organization of $\mathrm{TiO}_{2}$-NT crystalline phases. $^{38}$ 


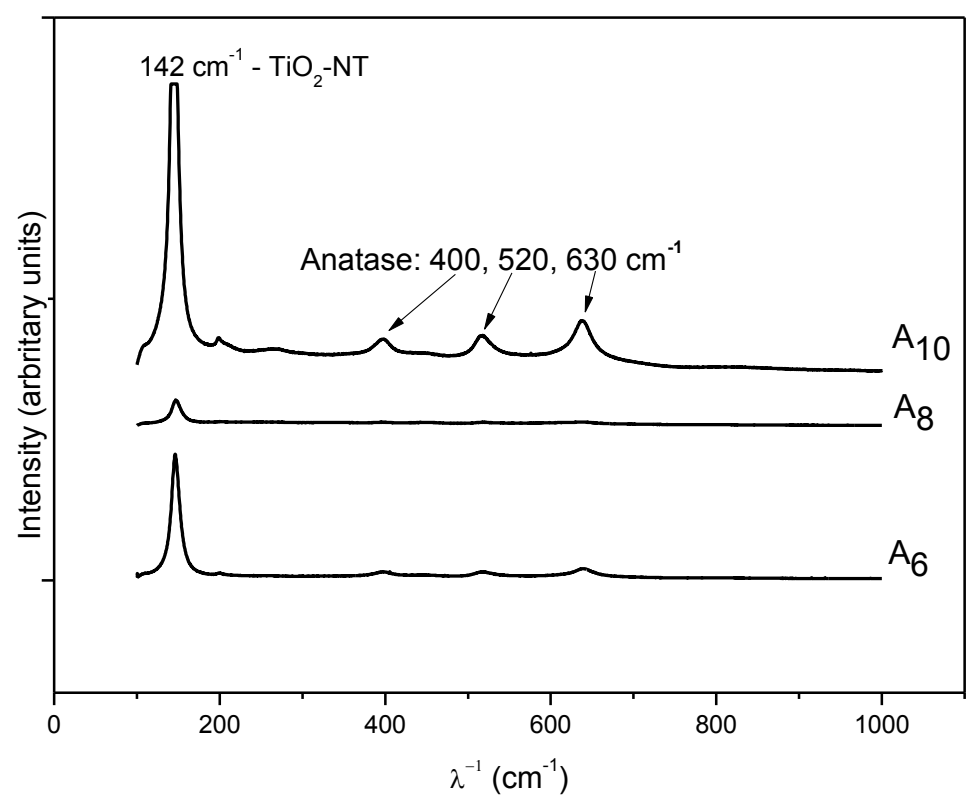

Figure 8. Raman Spectra of samples $A_{6}, A_{8}$ and $A_{10}$ after the heat treatment

During the heat treatment in under inert atmosphere, the $\mathrm{TiO}_{2}-\mathrm{NT}$ exhibited a crystallinity increase, with a phase transition from anatase to rutile at temperatures higher than $500{ }^{\circ} \mathrm{C}^{14}$. This transition occurs due to the higher stability of the rutile phase, however, in the present work the rutile phase was not formed during the heat treatment under inert atmosphere. The comparison between the parameters described in the literature and those used in the present work suggests that temperature $\left(500{ }^{\circ} \mathrm{C}\right)$, isotherm time $(3 \mathrm{~h})$ and heating rate $\left(25^{\circ} \mathrm{C} / \mathrm{min}\right)$ are the most influent factors for obtaining the nanostructure and crystalline structure of $\mathrm{TiO}_{2}$-NT with the characteristics listed. Smaller heating rates probably promote slower crystallization and preserve the anatase phase and, for applications such as photocatalysis, the treatment described is of key importance, due to the higher crystallinity and stability of the anatase phase.

\subsection{Photocatalytic efficiency}

The photocatalytic degradation efficiency was evaluated for samples $A_{6}, A_{8}$ and $A_{10}$ after the heat treatment, using a chloroform solution, for which the oxidation (photocatalytic) and the analysis of chemical oxygen demand (COD) were performed. Table 2 lists the degradation results using the UV radiation and UV radiation with $\mathrm{TiO}_{2}-\mathrm{NT}$ samples.

The presence of $\mathrm{TiO}_{2}$-NT increased the efficiency of the photocatalytic degradation process, as expected. Sample $A_{6}$ associated to UV radiation led to $51.58 \%$ chloroform degradation, while UV radiation (without the titanium oxide) was responsible for $31.69 \%$ of photodegradation, as listed in Table 2. After $1 \mathrm{~h}$, the use of $\mathrm{TiO}_{2}-\mathrm{NT}$ has increased photodegradation to $62.76 \%$. On the other hand, the sample $A_{10}$ exhibited a $5 \%$ increase.

The photocatalytic activity observed is probably a consequence of the crystalline structure since, after the heat treatment, samples $A_{6}$ and $A_{8}$ exhibited a well-defined peak at $25^{\circ}$ attributed to the (101) plane of anatase phase according to XRD analysis (Figure 6). This indicates that the anatase phase is responsible for the photocatalytic properties of the samples according to the literature. $^{39}$ According to Kondo $\mathrm{M}$. and Jardim W. F. the photodegradation using $\mathrm{TiO}_{2}$ particles in 1 hour reached $44 \%$ degradation 
of the $200 \mathrm{mg} / \mathrm{L}$ chloroform solution. Thus, it was observed that there was an increase in both the rate of degradation chloroform as the amount of degraded 1 hour of reaction. So, it is observed that the material has a great advantage over chloroform data available in the literature. ${ }^{40}$ Using samples $A_{6}$ and $A_{8}$ were observed $695 \%$ and $510 \%$, respectively, of increase of chloroform degradation perceptual compared to the Kondo and Jardim work. ${ }^{41}$

Table 2. Photocatalytic results of chloroform degradation using $A_{6}, A_{8}$ and $A_{10}$ samples after heat treatment

\begin{tabular}{|c|c|c|c|}
\hline Sample & COD variation (UV only) & COD variation (UV + sample) & Increase \% \\
\hline $\mathrm{A}_{6}$ & 31.69 & 51.58 & 62.76 \\
\hline $\mathrm{A}_{8}$ & 31.69 & 46.27 & 46.00 \\
\hline $\mathrm{A}_{10}$ & 31.69 & 33.47 & 5.62 \\
\hline
\end{tabular}

\section{Conclusions}

In the present work, $\mathrm{TiO}_{2}$ nanotubes $\left(\mathrm{TiO}_{2-}\right.$ NT) were synthesized by potentiostatic anodization under different $\mathrm{NaF}$ concentrations and the photocatalytic properties of $\mathrm{TiO}_{2}-\mathrm{NT}$ were evaluated in a chloroform aqueous solution. The anodization method was efficient for production of $\mathrm{TiO}_{2}$-NT and scanning electron microscopy showed the formation of nanotube arrays homogeneously dispersed obtained from 0.18 and $0.36 \mathrm{M} \mathrm{NaF}$ aqueous solutions with 25 and $30 \mathrm{~V}$ and $4 \mathrm{~h}$.

The heat treatment was effective for the crystallinity control, since the anatase phase was the only obtained at $500{ }^{\circ} \mathrm{C}$ under the conditions employed. The nanostructure control was successfully performed by varying the syntheses conditions, temperature and heating rate. The chemical oxygen demand tests in chloroform aqueous solutions confirmed the photocatalytic activity of $\mathrm{TiO}_{2}$-NT. The results using samples $A_{6}$ and $A_{8}$ shown an increase in the amount of chloroform degradation compared to the literature.

\section{Acknowledgements}

The authors would like to thank the support from FAPERJ and UEZO, INT, EQ-UFRJ (LABTARE e LabTecH) for the development of this work.

\section{References}

${ }^{1}$ lijima, S. Mater. Sci. Eng., B 1993, 19, 172. [CrossRef]

${ }^{2}$ Rao, C. N. R.; Müller, A.; Cheetham, A. K., The Chemistry of Nanomaterials: Synthesis, Properties and Applications, 1a ed., Wiley: Germany, 2004. [CrossRef]

${ }^{3}$ Wang, Z. L.; Characterization of Nanophase Materials, 1a ed., Wiley: Germany, 2000.

${ }^{4}$ Kasuga, T. Thin Solid Films 2006, 496, 141. [CrossRef]

${ }^{5}$ Yuan, Z-Y.; Su B-L., Colloid. Surface A 2004, 241, 173. [CrossRef]

${ }^{6}$ Macak, J. M.; Tsuchiya H.; Ghicov, A.; Yasuda, K.; Hahn, R.; Bauer, S.; Schmuki, P. Curr. Opin. Solid St. M. 2007, 11, 3. [CrossRef]

${ }^{7}$ Yu, X.; Li, Y.; Wlodarski, W.; Kandasamy, S.; Kalantar-Zadeh, K. Sensor Actuat. B-Chem. 2008, 130, 25. [CrossRef]

${ }^{8}$ Liu, R.; Yang, W.-D.; Qiang, L.-S.; Wu J.-F. Thin Solid Films 2011, 519, 6459. [CrossRef]

${ }^{9}$ Klein, C.; Hurlbut, J.; Dana, J. D.; Manual of Mineralogy, 21a ed., Wiley: New York, 1999.

${ }^{10}$ Filho, E. A.; Fraga, A. F.; Bini, R. A.; Marques, R. F. C.; Guastaldi, A. C. Revista Matéria 2009, 14, 787. [Link] 
11 Paulose, M.; Mor, G. K.; Varghese, O. K.; Shankar, K.; Grimes, C. A. J. Photochem. Photobio. A 2006, 178, 8. [CrossRef]

12 Ni, M.; Leung, M. K. H.; Leung, D. Y. C.; Sumathy, K. Renew. Sust. Energ. Rev. 2007, 11, 401. [CrossRef]

13 Li, L.-H.; Kong, Y.-M.; Kim, H.-W.; Kim, Y.W.; Kim, H.-E.; Heo, S.-J.; Koak, J.-Y. Biomaterials 2004, 25, 2867. [CrossRef]

${ }^{14}$ Fang, D.; Luo, Z.; Huang, K.; Lagoudas, D. C. Appl. Surf. Sci. 2011, 257, 6451. [CrossRef]

15 Li, G.; Liu, Z.-Q.; Lu, J.; Wang, L.; Zhang, Z. Appl. Surf. Sci. 2009, 255, 7323. [CrossRef]

${ }^{16}$ Zwilling, V.; Aucouturier, M.; DarqueCeretti, E. Electrochim. Acta 1999, 45, 921. [CrossRef]

17 Paramasivam, I.; Macak, J. M.; Selvam, T.; Schmuki, P. Electrochim. Acta 2008, 54, 643. [CrossRef]

${ }^{18}$ Kolinko, P. A.; Kozlov, D. V.; Vorontsov, A. V.; Preis, S. V. Catal. Today 2007, 122, 178. [CrossRef]

${ }^{19}$ Mor, G. K.; Varguese, O. K.; Paulose, M.; Ong, K. G.; Grimes, C. A. Thin Solid Films 2006, 496, 42. [CrossRef]

${ }^{20}$ Chen, L.-C.; Ho, Y.-C.; Guo, W.-S.; Huang, C.-M.; Pan, T.-C. Electrochim. Acta 2009, 54, 3884. [CrossRef]

${ }^{21}$ Mor, G. K.; Varguese, O. K.; Paulose, M.; Shankar, K.; Grimes, C. A. Sol. Energ. Mater. Sol. Cell. 2006, 90, 2011. [CrossRef]

22 Grimes, C. A.; Mor, G. K.; $\mathrm{TiO}_{2}$ Nanotube Arrays: Synthesis, Properties and Applications, 1a ed., Springer: New York, 2009.

${ }^{23}$ Wang, D.; Yu, B.; Zhou, F.; Wang, C.; Liu, W. Mater. Chem. Phys. 2009, 113, 602. [CrossRef]

${ }^{24}$ Gong, D.; Grimes, C. A.; Varghese, O. K.; $\mathrm{Hu}$, W.; Singh, R. S.; Chen, Z.; Dickey, E. C. J. Mater. Res. 2001, 16, 3331. [CrossRef]

${ }^{25}$ Macak, J. M.; Sirotna, K.; Schmuki, P. Electrochim. Acta 2005, 50, 3679. [CrossRef]
${ }^{26}$ Rani, S.; Roy, S. C.; Paulose, M.; Varghese, O. K.; Mor, G. K.; Kim, S.; Yoriya, S.; LaTempa, T. J.; Grimes, C. A. Phys. Chem. Chem. Phys. 2010, 12, 2780. [CrossRef]

${ }^{27}$ Filho, J. T.; Rocco, A. M. Revista de Ciência \& Tecnologia 2012, 12, 20. [Link]

${ }^{28}$ Gerven, T. V.; Mul, G.; Moulijn, J.; Stankiewicz, A. Chem. Eng. Process. 2007, 46, 781. [CrossRef]

29 Beranek, R.; Hildebrand, H.; Schmuki, P. Electrochem. Solid-State Lett. 2003, 6, B12. [CrossRef]

${ }^{30}$ Zhao, J.; Wang, X.; Sun, T.; Li, L. J. Alloy. Compd. 2007, 434, 792. [CrossRef]

${ }^{31} \mathrm{Xu}, \mathrm{Y}$.; Shen, M. J. Mater. Process. Tech. 2008, 202, 301. [CrossRef]

32 Macak, J. M.; Schmuki, P. Electrochim. Acta 2006, 52, 1258. [CrossRef]

${ }^{33}$ Xiao, P.; Garcia, B. B.; Guo, Q.; Liu, D.; Cao, G. Electrochem. Commun. 2007, 9, 2441. [CrossRef]

${ }^{34}$ Chanmanee, W.; Watcharenwong, A.; Chenthamarakshan, C. R.; Kajivichyanukul, P.; de Tacconi, N. R.; Rajeshwar, K. Electrochem. Commun. 2007, 9. 2145. [CrossRef]

${ }^{35}$ Kang, S. H.; Kim, J.-Y.; Kim, H. S.; Sung, Y.-E. J. Ind. Eng. Chem. 2008, 14, 52. [CrossRef]

${ }^{36}$ Xiao, X.; Ouyang, K.; Liu, R.; Liang, J. Appl. Surf. Sci. 2009, 255, 3659. [CrossRef]

${ }^{37}$ Yang B.; Ng, C. K.; Fung, M. K.; Ling, C. C.; Djurisic, A. B.; Fung, S. Mater. Chem. Phys. 2011, 130, 1227. [CrossRef]

${ }^{38}$ Li, H.; Cao, L.; Liu, W.; Su, G.; Dong, B. Ceram. Inter. 2012, 38, 5791. [CrossRef]

${ }^{39} \mathrm{Hu}$, M. Z.; Lai, P.; Bhuiyan, M. S.; Tsouris, C.; Gu, B.; Paranthaman, M. P.; Gabitto, J.; Harrison, L. J. Mater. Sci. 2009, 44, 2820. [CrossRef]

${ }^{40}$ LI, X.; Zou, X.; Qu, Z.; Zhao, Q.; Wang, L. Chemosphere 2011, 83, 674. [CrossRef]

${ }^{41}$ Kondo, M. M.; Jardim W. F. Water Res. 1991, 25, 823. [CrossRef] 